\title{
$4-1-1984$
}

\section{The Evolution of Law: The Roman System of Contracts}

\author{
Alan Watson \\ University of Georgia School of Law, wawatson@uga.edu
}

b

\section{Repository Citation}

Alan Watson, The Evolution of Law: The Roman System of Contracts (1984),

Available at: https://digitalcommons.law.uga.edu/fac_artchop/496

This Article is brought to you for free and open access by the Faculty Scholarship at Digital Commons @ University of Georgia School of Law. It has been accepted for inclusion in Scholarly Works by an authorized administrator of Digital Commons @ University of Georgia School of Law. Please share how you have benefited from this access For more information, please contact tstriepe@uga.edu. 


\title{
The Evolution of Law: The Roman System of Contracts
}

\begin{abstract}
Alan Watson
I have two aims in producing this paper. First, I wish to contribute to the general understanding of how and why law develops and explain the evolution of some very familiar legal institutions. Second, I wish to add to our knowledge of the history of Roman law, by producing a radically different view of the development of contracts, that is, I believe, both consistent with surviving textual data and plausible with regard to human behavior.

Roman law has been the most innovative and most copied system in the West; the law of contract was the most original and the most admired part of that system. Private agreements and applicable law occupy a central role in mercantile countries - indeed, in the Western world in general, and one would expect on a priori grounds that this branch of law would illuminate the whole subject of legal development and law in society. This is especially true in that a contract is a private agreement, almost a private law, operating between two individuals but requiring state recognition. The state may be either slow or quick to give such recognition: slow as in England where by the late twelfth century, the central royal courts exercised much jurisdiction over property law and criminal law but little over contract; ${ }^{1}$ quick as in Rome where before 451 B.C. stipulatio could be used to make a legally enforceable agreement. The state may also have reservations about recognizing private agreements. It may be willing to enforce only agreements with specified minimum value - only those considered to have sufficient social or economic interest to the state. Or it may restrict its recognition to agreements concluded with specified formalities, the formalities might constitute an evidentiary justification or impress on the parties the seriousness of what they were doing. Or it may restrict its recognition to agreements of a particular subject matter. For instance, in Rome, the law enforced an agreement to exchange goods for money but not an agreement to exchange goods for services.
\end{abstract}

Alan Watson is Professor of Law at the University of Pennsylvania Law School.

This paper is for David Daube, on his 75th birthday. I am grateful to my friends, John L. Barton, Stephen B. Burbank, Charles Donahue, Jr. and Michael H. Hoeflich, who read a draft of this paper and gave valuable criticisms. A version of this paper was also delivered before the Jurisprudence and Social Policy Program of the University of California at Berkeley and before the Classics Department of Stanford University in November 1983, and I received many useful comments. As always, my greatest debt, directly and indirectly, is to my master, David Daube.

1. See Glanvil, The Treatise on the Laws and Customs of the Realm of England Commonly Called Glanvill, ed. G.D.C. Hall, Tractatus de Legibus et Consuetudinibus Regni Anglie (London, 1955) X. 18; see, e.g., A.W.B. Simpson, A History of the Common Law of Contract (Oxford, 1975) 4. 
State recognition may involve various combinations of restrictions. For example, the French Code civil, art. 1341, provides that any agreement above a very tiny sum, although it is valid as a contract, is not susceptible of proof in court unless there is a written document either accepted by a notary or signed by the parties; ${ }^{2}$ and the German Bürgerliches Gesetzbuch, §518 requires that in order for a gift agreement to be enforceable it be recorded judicially or notarially.

The immediate aim of the present paper is to account for the recognition by the Roman state of the individual types of contract, such as deposit and sale; to show why they arose individually in the chronological order that they did; to indicate why the dividing lines between one contract and another are as they are; and to explain why other contracts, such as a general contract in writing did not arise or, as in the case of barter, arose only late and with unsatisfactory rules. It will become apparent that, although economic or social reasons demanded the introduction of each type, it was the legal tradition that determined the nature, structure and chronology of every contract. The basic structure of Roman contract law developed without reference to and then lived in spite of any societal justification for the divisions.

The starting point in time of this inquiry is the era shortly before the enactment of the Twelve Tables, the earliest Roman codification, which is traditionally and, I think, accurately attributed to around 451-50 B.C. ${ }^{3}$ And I will tentatively and possibly rather crudely define 'contract' for present purposes as an agreement between two or more persons whose main legal consequence is an obligation with an effect personal rather than real. There is, of course, in any investigation of a legal system from a very different time and place always an initial difficulty of categorization. The question is specifically whether the Romans of that time conceived the notion of contract as we do. The answer is probably no, that in fact the Romans had no abstract concept of 'contract.' That term as used here includes, in the early fifth century B.C. the contract of stipulatio, but it excludes conveyances like mancipatio and in jure cessio and security transactions like nexum, even though the latter also possess elements of obligation based on agreement. This separation may seem unfortunate. But there are three reasons to accept the limitation on the term contract. First, our knowledge of the Twelve Tables is limited, and we have no evidence that the early Romans would have classified stipulatio with mancipatio and the others. Secondly, this categorization allows us to include all of the obligations that later Romans regarded as contractual and to exclude all obligations that later Romans did not regard as contracts. Thirdly, the modern perspective has grown out of the ideas that the Romans developed. ${ }^{4}$

2. But there are exceptions.

3. For the argument see, e.g., Alan Watson, Legal Transplants (Edinburgh, 1974) 15.

4. Mancipatio was a formal ceremony needed to transfer certain important kinds of property, and its obligational content was an inherent warranty against the eviction of the transferee from the property. Nexum is obscure, is probably a variant form of mancipatio, and it involved a creditor having real rights over the person of the nexus: see, 
It is often said that the Romans never developed a system of contract but only of individual contracts, ${ }^{5}$ and the attempt is sometimes made to explain in economic terms why each contract arose when it did. Such attempts are doomed to failure because no investigation into contracts one by one and separately can make sense in economic terms of the order of their appearance. For instance, the contract of deposit appears in the fifth century B.C., loan for consumption in the third century B.C. at the latest, but barter, insofar as it was ever a contract at all, had to wait at least another few hundred years; all this occurred while there was no contract of sale until about 200 B.C. Again, there was no specific contract for reward for looking after a thing, reward in return for another's use of one's thing, or reward for one's services until, after the advent of coined money, the introduction of the contract of hire sometime close to 200 B.C. In these circumstances, the early dating, before 123 B.C., ${ }^{6}$ of the invention of a contract of mandate where someone agreed to act gratuitously for another-and the essence of the contract specified that the performance be gratuitous-seems unlikely if the need for the contract is to be explained on economic grounds.

The truth is more complicated, but if one is prepared to grant an important role for legal development to the legal tradition, then the unfolding of the growth of Roman contracts is rational and simple to explain. From very early times the Romans had a method, the stipulatio, by which parties could agree to create any obligation as long as it was not positively unlawful. If one dares to speak probably anachronistically, one can say that in very early times the Romans did have a general theory of contract, not a law of individual contracts. The question to be resolved then is how did this general approach to contract come to be lost? The clue to the development lies in a very strange fact that needs an explanation: apart from the very special and complex case of partnership, all Roman contracts either have a money prestation or no prestation. In this latter category are two kinds of contract: they may either be gratuitous of necessity or they are unilateral (in which case they may be matched with another contract). What does not exist, apart from the late and uncertain instance of barter, is a Roman contract where goods or, in a different case, services are proffered in return for goods and services. What is striking, moreover, is that in deciding which contract is involved, the touchstone is whether performance is necessarily (so far as the contract goes) for nothing or whether the performance is for money. For instance, depositum, commodatum (loan for use) and mandatum all become hire (locatio conductio) if payment is

e.g., Max Kaser, Das römische Privatrecht I, 2d ed. (Munich, 1971) 165ff.; Alan Watson, Rome of the XII Tables (Princeton, 1975) $11 \mathrm{ff} ., 134 \mathrm{ff} . ;$ György Diósdi, Contract in Roman Law (Budapest, 1981) 30 ff. It is Diósdi who would add in iure cessio as involving an obligation. It was a fictional law suit to effect the transfer of ownership in which the defendant, the owner, put up no defense to a claim of ownership from the plaintiff, the transferee. None of these three institutions had a major impact on the later development of the law of contract.

5. See, e.g., J.A.C. Thomas, A Textbook of Roman Law (Amsterdam, 1976) 226.

6. Rhetorica ad Herennium, 2.13.19. 
promised. What is so significant about a prestation in coined money that a Roman contractual type must either contain it or be gratuitous? The solution to the problem of development, I submit, is that in most cases an individual type of Roman contract arose subsequently to stipulatio when, for whatever reason, a stipulatio was inappropriate or inefficient for that type of situation and when there was a societal need. Thus, almost every subsequent contractual type is a derogation from stipulatio. It may at this stage be worth stating expressly that a legal remedy on an agreement is needed not in accordance with the frequency of important transactions but in accordance with the frequency of their going wrong.

The origins of the stipulatio ${ }^{7}$ are obscure, and may have involved a libation or an oath, but they need not concern us now, ${ }^{8}$ nor should further conclusions be drawn from any hypothesis as to origins. What matters is that it was well developed before the time of the Twelve Tables, under which the contract was actionable by the form of process known as legis actio per iudicis postulationem. ${ }^{9}$ It was a formal, and unilateral contract in which the promisee asked: 'Do you promise (whatever it might be)?' necessarily using the verb spondere, and the promisor immediately replied: 'Spondeo' ('I promise'), using the same verb. Later, other verbs could be used, but spondere could only be used by Roman citizens. The content of the promise was judged only by the words used, and the contract would remain valid and effective even if the promise was induced by fraud, extorted by fear or proceeded on an error. Stipulatio could be used for any lawful purpose: to promise a dowry, make a sale (when mutual stipulationes would be needed), engage one's services, ${ }^{10}$ and so on. But when an agreement was not cast in the form of a stipulation then, no matter how serious the intention of the parties, no matter how important the subject matter of the transaction, there was no contractual obligation and no right to any disappointed party to bring a contractual action.

Stipulatio, by skillful modernization, could have become the root of a flexible, unitary contractual system. Writing, perhaps incorporated into two documents, could have been adopted as an alternative to the oral promise and answer, or agreement (however it was proved) could have become the basis of a contract; remedies for fraud, intimidation, or error could have been made inherent in the contract; and implied terms could have been developed for specific factual situations. Instead, a number of other individual contracts arose, each defined in terms of its function. This definition by function and not by form separates them sharply from stipulation. They might even appear to be lesser breeds, particular rather

7. Also known as the sponsio.

8. See e.g., Max Kaser, Das altrömische Ius (Göttingen, 1949) 256 ff.; H. van den Brink, Ius Fasque, Opmerkungen over de Dualiteit van het archaisch-romeins Recht (Amsterdam, 1968) 172ff; Okko Behrends, Der Zwölftafelprozess (Göttingen, 1974) 35-36; and the authors they cite.

9. G. $4.17 \mathrm{a}$.

10. See, e.g., Kaser, Privatrecht I, supra note 4, $168 \mathrm{ff}$. 
than general. Each of the contractual arrangements, however, whether it be loan for consumption or sale, could be cast in the form of one or more stipulationes, and then would be that latter type of contract.

One early contract was mutuum, loan for consumption. Mutuum was provided with the action known as the condictio, which lay when the plaintiff's claim was that the defendant was the owner of a thing which he was under a legal duty to deliver to the plaintiff. Many scholars believe mutuum to be very old with a prehistory before it came to be provided with the condictio - and if so, the general argument of this paper is strengthenedbut much that is peculiar about the condictio is explicable, as we shall see, if we link the introduction of that action with the creation of mutuum as a legal institution. The legis actio per condictionem was introduced by the lex Silia when what was claimed was a determinate sum of money, the lex Calpurnia when what was claimed was a definite thing. ${ }^{11}$ It is usually held that the lex Silia was earlier on the basis that otherwise there would be no need for a law specifically covering money. ${ }^{12}$ David Daube, as we shall see, adds a new dimension. In any event, whatever the priority of these two statutes may have been, the remedy of the condictio is old. As early as the composition of the Rudens by Plautus, who died in 184 B.C., the classical procedure by formula could be used for the condictio as well as the archaic procedure by legis actio. ${ }^{13}$ And there would be little point in setting up fresh legis actiones once formulae were in being.

The peculiarities of the condictio are that it is abstract in the sense that the plaintiff does not set out in the pleadings the grounds of his case; it is general in that it can be brought any time a nonowner believes that the owner of money or a certain thing is under a legal obligation to give it to him; ${ }^{14}$ and that, apart from exceptional cases, there had to be a preceding delivery of the thing to the defendant by the plaintiff. Thus, the condictio could be brought both where there was and where there was not a contract. ${ }^{15}$ The generality coupled with the abstraction requires explanation, and the simplest explanation is that the condictio was originally envisaged for one concrete situation - and was found to be extendable to others - which was so obvious that it did not have to be expressly set out. The most obvious concrete situation is mutuum, which in fact has always been treated as the primary use of the condictio. Loan for consumption would need to be given legal effectiveness when there was a breakdown in neighborly relations, when one friend failed to repay a loan: in an early agricultural community a loan of seed corn to be repaid after the harvest would be a common case. No stipulation would have been taken precisely because it is morally inappro-

11. G. 4.19 .

12. See e.g., Kaser, Privatrecht I, supra note 4, 170-71.

13. See for the argument, Alan Watson, Roman Private Law around 200 B.C. (Edinburgh, 1971) 126-27.

14. The condictio furtiva which is exceptional need not concern us here.

15. See e.g., Kaser, Privatrecht I, supra note 4, 492-93. 
priate for one friend, performing an amicable service, to demand a formal contract from another. 16 Where the loan was commercial, a stipulation would have been taken, to cover interest as well, and there would be no need for a specific contract of mutuum. We now see also why the action on mutuum was for the principal only and did not extend to interest: friends do not demand interest from friends. ${ }^{17}$ The breakdown in neighborly relations might be related to an increase in Rome's size.

But the earliest action for a mutuum was apparently for money, not for seed corn. This is explained by David Daube in a wide framework. ${ }^{18} \mathrm{He}$ stresses that "some transactions, originally belonging to the gift area of fellowship, "Gemeinschaft," tend to assume the more rigid, legalistic characteristics of partnership, "Gesellschaft," when money enters.' Specifically with regard to mutuum, the giving of an action-at first restricted to a money loan - marks for him a breakdown in the gift trade. ${ }^{19}$ Earlier, a gift of corn or money to a friend in need was expected to be returned by a converse gift at an opportune time. I would prefer to think that even before the lex Silia, the idea of mutuum was that of a loan to be returned in due course, but that is a minor matter. What is significant is that Daube offers a plausible explanation for the condictio being originally restricted to a claim for money.

Deposit was, I believe, another early specific type of contract. The jurist Paul tells us: 'On account of deposit an action is given by the Twelve Tables for double, by the praetor's edict for single. '20 It has long been held that the action for double under the Twelve Tables, being penal, was not necessarily based on any concept of contract and was closer to delict. ${ }^{21} \mathrm{~A}$ further

16. In French law any noncommercial (in the technical sense) transaction above a very small amount can be proved only by a notarial act or a private signed writing except, under art. 1348 of the Code civil, when it is not possible for the creditor to procure writing. 'Possible' here refers to moral possibility as well as physical, and in certain close relationships, such as those involving one's mother, mistress or physician, the obtaining of a writing is regarded as morally impossible.

17. Some scholars, for instance Kaser, Ius, supra note 8,286 , suggest that a real action, the legis actio sacramento in rem, was available for mutuum before the introduction of the condictio. There is no evidence for this, and the availability of such an action would make it more difficult to explain the introduction of the condictio. But the suggestion would not adversely affect the idea expressed here that mutuum was given specific protection because the arrangement was among friends and stipulatio was morally inappropriate. At whatever date, a commercial loan would involve interest, a stipulatio would be taken, and there would be no need for specific legal protection of mutuum.

18. David Daube, 'Money and Justiciability,' Zeitschrift der Savigny-Stiftung (rom. Abt.) (1979) lff.

19. Ibid. 11. See earlier David Daube, 'The Self-Understood in Legal History,' Judicial Review 18 (1973) 120, 129-30.

20. Collatio 10.7.11. The action has often been thought to be something other than an action for deposit or to be an action for what was later called depositum miserabile but see now, e.g., Watson, Roman Private Law, supra note 13, 151; Kaser, Privatrecht I, supra note 4,160 n.49.

21. See, e.g., Watson, Roman Private Law, supra note 13, 157; Kaser, Privatrecht I, supra note 4,160 . 
suggestion is sometimes made that the delict is akin to theft. ${ }^{22}$ But what must be stressed at this point is the very restricted scope of the action. It lies, if we believe Paul, where a thing that was deposited is not returned: it does not lie, according to Paul's words, and no similar ancient action we know of lies, if a thing that was hired out or lent for use is not returned or even if a fee were to be paid for looking after the deposited property. Moreover, apart from questions of contract, there seems little need for the action. The owner would have the normal action (of the time) claiming ownership, the legis actio sacramento in rem, and he would have the action for theft if the depositee moved the thing (and it would be of little use to him if he did not). There seems little reason to single out this particular situation for a specific action based on the notion of delict.

What then would impel the desire for a specific action? Deposit differs from hire of a thing and loan for use first in that the object deposited is being taken out of circulation - no one can use it, certainly not the depositee, for the contract is definitely not for the benefit of the depositee. Secondly, in deposit it is precisely the recipient who is bestowing the favor. It follows that the depositor is in no position to demand that the recipient formally promise by contract to restore the thing - the depositor cannot reward the depositee for his good deed by showing doubts about his honesty. Again, the reason the depositor is willing to have his property out of circulation for a time is often that he finds himself in an emergency and cannot look after the property himself - as a result of earthquake, fire, collapse of a building or shipwreck - and here too, he is in no position to demand the formality of a stipulation from his helper. But the depositor is particularly vulnerable to fraud, and it is reasonable to give him a forceful remedy with penal damages. In the late Republic, the praetor issued a complicated edict on deposit $^{23}$ of which the main clauses gave an action for double damages against a depositee who fails to return property entrusted to him in what is called depositum miserabile - deposit made as a result of earthquake, fire, collapse of a building or shipwreck - and an action for simple damages in other cases. Arguments have been produced both for the proposition that the Twelve Tables' provision applied only to depositum miserabile ${ }^{24}$ and also for the proposition that it applied to deposits of all kinds. The arguments seem inconclusive, though I tend to favor the second and more usual view, but in either eventuality the argument given here for an early specific action in fraud would fit. The strength of feeling that the depositor should have an action in the event of fraud would be intensified if, as seems likely, deposits were frequently made in temples or with priests. ${ }^{25}$

22. E.g., ibid. 160 .

23. See, e.g., Otto Lenel, Das Edictum Perpetuum, 3d ed. (Leipzig, 1927) 288-89.

24. The literature is enormous, but see, e.g., W. Litewski, 'Studien zum sogenannten "depositum necessarium," 'Studia et Documenta Historiae et Iuris 43 (1977) 188ff, especially at 194ff., and the works he cites.

25. Cf., e.g., Plautus, Bacchides, 306. 
One of the great Roman inventions - it is now widely accepted that there were no foreign models ${ }^{26}$ - is the consensual contract, a contract that is legally binding simply because of the parties' agreement and that requires no formalities for its creation. There were four of these, and it is generally presumed that the contract of sale, emptio venditio, was the earliest. It seems to me to have been fully actionable by around 200 B.C. ${ }^{27}$ There have been numerous theories to explain the origins of consensual sale. ${ }^{28}$ Some of these, such as the hypothesis that at one time the agreement became binding only if the buyer had given the seller an earnest of his payment of the price or only if the seller had delivered to the buyer, are now seen to lack support from the sources. Other theories attempt to explain how Romans got the idea that agreements without formality might be actionable. For instance, Theodor Mommsen's work on state contracts, involving the public sale of booty, is an example. ${ }^{29}$ Mommsen's theory provides no insight, however, into the transformation of private bargains into contracts of sale which, though made by private individuals, were enforced by the courts. There may be more than one root in the development of the consensual contract. But whatever economic or social pressures one wants to postulate, whether one says consensual sale was wanted because (as some think) of an expansion of foreign trade and contracts were wanted which could be made at a distance, or because (as others hold) a formless contract was needed since foreign merchants were unfamiliar with Roman law formalities, or because (as still others argue) a growing awareness of the value of good faith in contract law arose in the context of dealings between Romans and foreigners, ${ }^{30}$ the same conclusion holds: consensual sale as a separate contract arose in part because of the inadequacy of the stipulatio for the task. There should be no doubt that before the introduction of the consensual contract, parties to a sale-type transaction who wanted legal enforcement of their agreement would make their arrangements in the form of stipulations. ${ }^{31}$ And further

26. See, e.g., Diósdi, Contract, supra note 4, 44-45.

27. See Alan Watson, Law of Obligations in the Later Roman Republic (Oxford, 1965) $40 \mathrm{ff}$.

28. See, e.g., Kaser, Privatrecht I, supra note 4, 546; Herbert F. Jolowicz and Barry Nicholas, Historical Introduction to the Study of Roman Law, 3d ed. (Cambridge, 1972) $288 \mathrm{ff}$., and the works they cite.

29. Theodor Mommsen, 'Die römischen Anfänge von Kauf and Miethe,' Zeitschrift der Savigny-Stiftung 6 (rom. Abt.) (1885) 260ff.

30. Scholars who take any one of these approaches also wish to give a central role in the invention to the peregrine praetor. This seems to me to be unnecessary, but the point need not detain us here: see Alan Watson, Law Making in the Later Roman Republic (Oxford, 1974) 63ff.

31. This appears even in Mommsen, 'Anfänge,' supra note 29, 260; see also, e.g., Ernst Immanuel Bekker, Die Aktionen des römischen Privatrechts I (Berlin, 1871) 156ff.; Vincenzo Arangio-Ruiz, La Compravendita in diritto romano I, 2d ed. (Naples, 1956) $57 \mathrm{ff}$. Diósdi objects, asking why it would be necessary to cut up 'the uniform contract of spot transactions into two separate contracts, to confirm the two promises with a stipulatio, then abandon the stipulationes shortly so that at the beginning of the preclassical age the contract appears as already in its classical shape.' Diósdi, Contract, supra note 4,45 . By spot transaction, he appears to have mancipatio in mind. There are 
development would not have occurred if this way of making the arrangement had been satisfactory.

My own version of the origins of consensual sale and the connection with stipulatio $^{32}$ derives from the observation of two defects in the contract of sale that continued to exist for centuries, namely that the contract did not contain any inherent warranty of title or against eviction nor any inherent warranty against latent defects. Yet buyers did want the protection of warranties, as hundreds of texts on the actual taking of warranties by stipulatio show. And the notion of inherent warranties was not foreign to Roman lawyers since they had already existed for centuries in the mancipatio, the formal method of transferring certain types of important property. The absence of inherent warranties would make the consensual contract far less valuable commercially. Whenever merchants wanted warranties - and the evidence shows that they often did-then the parties had to be face-to-face to take a stipulation; hence, the contract could not be made by letter or messenger. Certainly, one could send a dependent member of one's family to take or give the stipulation, but that in itself would often be inconvenient and expensive. ${ }^{33}$ The absence of inherent warranties for centuries, the strong Roman desire for warranties, and their knowledge that warranties could be implied, demand an explanation which I believe can be found only if we postulate an origin for the contract where the deficiencies were not so obvious. ${ }^{34}$

If we go back beyond the origin of sale, the parties to a sale-like arrangement who wished a legally binding agreement would, as I have said, conclude their business by stipulations. All terms, given the nature of stipulatio, would have to be spelled out. The buyer would promise payment on a fixed date, with interest if he delayed. The seller would promise that he would deliver the thing on a fixed day, to pay a penalty if he delayed, that the buyer would not be evicted from the thing, and that the thing was free

two flaws in this argument. First, the object of the sale-type transaction would not always be a res mancipi, in which case mancipatio would be inappropriate, Secondly, even in the earliest times, even when the object was a res mancipi, the parties would not always want a spot transaction, but delivery at a later time, and mancipatio would not then be used.

32. Alan Watson, 'The Origins of Consensual Sale: a Hypothesis,' Tijdschrift voor Rechtsgeschiedenis 32 (1964) 245ff.

33. In fact, the stipulatio could not be taken from a son or slave with full protection until the introduction of the actio quod iussu. That action appears to be based on an edict of the praetor (Lenel, Edictum, supra note 23, 278) and actions based on an edictal clause which gives the plaintiff a new right of action cannot be safely dated back beyond around 100 B.C.; see Watson, Law Making, supra note 30, 38.

34. Nicholas does not agree, and suggests for the persistence of the stipulations that they imposed strict liability whereas liability on sale would be based only on good faith: Jolowicz and Nicholas, Introduction, supra note 28,289 n.8 (at p. 290). This does not address the problem, which is not the continued use of stipulatio but the absence of implied warranties in sale. Those who wanted strict liability could still have demanded a stipulatio even if emptio venditio had implied warranties. Again, this approach does not lessen the commercial inconvenience of the lack of implied warranties. Moreover, it must be surprising in a contract of sale which is based on good faith that there is no warranty of title or of quiet possession. 
from hidden defects. Each stipulatio was unilateral, but the parties would want their rights and duties to be reciprocal, hence the obligation to fulfill each stipulatio would have to be made conditional upon the fulfillment of, or the readiness to fulfill, the other. To make matters worse, this conditional reciprocity would have to be framed so as to take account of a partial, but not complete, failure to perform. For instance, if a purchased slave were found to be suffering from some relatively unimportant defect, the buyer might still wish to retain the slave but pay a reduced price. The drafting and taking of the stipulations would be extremely cumbrous and complex, and often it would happen that the parties'intentions would be frustrated. So far we are on sure ground. What follows is a conjectural, but I think plausible, account of how the praetor, the magistrate in charge of the law courts, would deal with the problem. At some point in time a praetor accepted that he ought to grant an action in accordance with good faith to cover accidental interstices in stipulations concerned with a sale. ${ }^{35}$ Above all he would seek to make the obligations reciprocal. In accordance with the Roman tendency to see law in terms of blocks, ${ }^{36}$ the strict law stipulatio and the new action based on good faith would be kept separate. But the position would be reached that provided there was a sale-type situation and at least one stipulatio, there would be an action to give the buyer or the seller an action against the other for an amount equal to what ought to be given or done in accordance with good faith. The separate contract of sale was in process of being born. But what would be the content of the necessary stipulation? In the simplest possible sale-type transaction there would be an immediate handing over of the money and the thing. The stipulation entered would cover only continuing obligations. It would be made only by the seller and would consist of a warranty against eviction and against latent defects. We know from the republican writer Varro that these warranties were contained in a single stipulation. ${ }^{37}$ Eventually, an action on emptio venditio would be given even when no stipulation was taken, but because of the way the contract emerged, it long provided no remedy if the buyer suffered eviction or the object contained hidden defects, provided that the seller had acted in good faith. Heavy stress is placed on good faith in emptio venditio whether this was the result of the way the contract emerged or, as many think, was part of the pressure for recognizing the contract. This suggested development has one further feature that renders it plausible. It avoids any sudden leap forward in legal thinking: it is bedded firmly on how parties to a sale-type transaction would conduct their business, and the gradual response of those in charge of law-making to the problems that arose. ${ }^{38}$

35. Strict textual proof is lacking, but a development from the strict law stipulatio to good faith emptio venditio can have been no other.

36. For this, see, Alan Watson, The Making of the Civil Law (Cambridge, Mass., 1981) 14ff.

37. de re rustica, $2.2 .4 ; 2.3 .4 ; 2.4 .5$.

38. The impact of the defects in early consensual sale would be less noticeable, of course, where what was sold was a res mancipi and it actually was delivered by mancipatio, which did have an inherent warranty against eviction. Even here, however, there was no warranty against latent defects. 
A second consensual contract, hire, locatio conductio, has more obscure origins. The usual assumption is that its beginnings are closely connected with those of sale and that sale was the more important case: either the example of sale was followed for hire, which is thus a later contract, or the impetus for recognizing a contract of sale impelled also, and simultaneously, the recognition of the less significant locatio conductio. The need to attach legal importance to good faith in contracts would, for instance, be one joint impelling factor. ${ }^{39}$ If one grants priority to sale, whether in time or in legal importance, then one fact emerges unequivocally in the case of hire, though strangely it appears never to have been noticed. Locatio conductio is a residual category for all types of bilateral agreement that are not sale and where the prestation of one of the parties has to be in money. This and this alone can account for the peculiarity that at least three very different contractual situations are included within it: the use of a thing for a time in return for money; providing one's labor for a time in return for money; the assignment of a specific task to be performed in return for money. In each of these situations the obligations of the party who is acting in return for money are very different. Any doubts that locatio conductio is a residual category must disappear when one notices that in the corresponding situations where no money is to change hands then the one contract is replaced by three: mandate, deposit, and loan for use. ${ }^{40}$ It is in the highest degree illuminating for the force of legal tradition in legal development that such a figure as locatio conductio came into being, remained unchanged in its scope throughout the Roman period, and still flourishes in some countries, such as France, Chile, and Argentina, as a contract today.

As a further indication that one need not, even within the Western tradition, draw the line between one type of contract and another exactly as it usually is drawn, it is worth observing that in the second century B.C. at Rome, an agreement to allow another to pasture his flock on one's land for the winter in return for a money payment was regarded as sale of the fodder. ${ }^{41}$ Classical Roman and modern law would treat the agreement as hire. The republican position was perfectly sensible and would have remained so in classical law, given the fact that sale did not involve a requirement to transfer ownership, but only to give quiet possession-in this

39. For views see, e.g., Jolowicz and Nicholas, Introduction, supra note 28, $294 \mathrm{ff}$. Significantly, one recent writer on ancient hire, H. Kaufman, offers no view on the origins of the consensual contract: H. Kaufman, Die altrömische Miete (Cologne, 1964).

40. Actually, locatio conductio is so obviously a residual category-every bilateral transaction involving a money prestation that is not sale is hire - that one need not start with the assumption of the priority of sale. From the very fact of the residual nature of hire one can deduce the priority of sale. Unless, that is, one were to argue (as I think no one would), that originally sale transactions were within the sphere of locatio conductio and that emptio venditio was carved out of the all-embracing contract.

Perhaps it should be expressly stated that the three gratuitous contracts just mentioned do not correspond to the three major types of locatio.

41. Cato, de agri cultura 149. 
case for the duration of the agreement. The standard warranties in sale against eviction and hidden defects would have been perfectly appropriate.

A third consensual contract, mandatum, mandate, was in existence by 123 B.C., ${ }^{42}$ but its raison d'être was different from emptio venditio and locatio conductio. Mandate is the agreement to perform a service gratuitously for another. It is not a commercial contract, but an agreement among friends and is thus again the type of situation in which a stipulation could not be demanded-neither from the friend who was asked to perform the service nor by the friend for repayment of his expenses. That the contract came into existence at all is a tribute to the great weight that the Romans placed upon friendship - friends were expected to do a great deal for one another. It may seem surprising that such a distinction is made between agreeing to act gratuitously for another and acting for reward, but the Roman attitude that labor degrades sufficiently explains it. This also explains why performance of artes liberales could not be the subject of locatio conductio. ${ }^{43}$

A similar explanation can account for the emergence of commodatum, a gratuitous loan for use, as a separate contract, probably around the beginning of the first century B.C.: ${ }^{44}$ one friend who lends gratuitously to a friend cannot demand a formal promise in return. The same holds for the remodelled obligation of deposit that probably arose around the same date.

The origins of pignus, pledge, as an individual contract are not so easily uncovered. As a real security transaction giving the creditor the right to a specific action pursuing the thing pledged wherever it might be, pignus appears to be relatively old, but this does not imply that pignus also gave rise to a contractual action. There is no evidence that there ever existed a contractual action at Roman civil law, ${ }^{45}$ but the praetor certainly gave one by his Edict no later than the first century B.C. ${ }^{46}$ At the very least, the praetorian action is much more prominent than any presumed civil law action, and its wording is revealing: 'If it appears that Aulus Agerius (the plaintiff) delivered to Numerius Negidius (the defendant) the thing which is the object of this action, as a pledge because of money that was owing; and that money has been paid, or satisfaction made on that account, or it was due to Numerius Negidius that payment was not made, and that thing has not been returned to Aulus Agerius, whatever the matter in issue will come to ...' and so on. There existed also the so-called iudicium contrarium

42. Rhetorica ad Herennium, 2.13.19: see, e.g., Alan Watson, Contract of Mandate in Roman Law (Oxford, 1961) 22.

43. See, e.g., Kàroly Visky, Geistige Arbeit und die Artes Liberales in den Quellen des römischen Rechts (Budapest, 1977) 146ff.

44. For the dating, see Watson, Law Making, supra note 30, 3 lff, especially 38.

45. See, e.g., Lenel, Edictum, supra note 23, 254ff., who, however, thinks there was such an action; and Kaser, Privatrecht I, supra note 4, 537, who apparently tends to think there was not.

46. See Watson, Obligations, supra note $27,182 \mathrm{ff}$. 
which was available to the creditor, ${ }^{47}$ but there is no doubt that the primary, and perhaps at one stage the sole, contractual action lay to the debtor against the creditor. The main thrust of introducing the contract was thus the protection of the debtor. The real security of pignus could be made without delivery, but, as the wording of the action indicates, there was a contract only if the pledge had been delivered to the creditor, and the contract gave rise to an action only when the debtor had repaid the loan or made satisfaction. Thus, in at least the great majority of cases, there could have been no physical obstacle to a stipulation. Even if delivery were not by the debtor personally but by someone in the power of the debtor, such as a son or slave, to the creditor, or delivery were made to someone in the creditor's power, a stipulation could have been taken which would be legally binding. The actio quod iussu which would (for our purposes) make a head of household liable for a stipulatio made on account of his transaction by one of his dependents is unlikely to be much later than contractual pignus. ${ }^{48}$ And since the transaction is commercial, moral obstacles to a stipulation of the kind already mentioned would not have existed.

Tentatively, I would suggest a possible reason for this introduction within the tradition of Roman contract law. It rests on the premise that in the normal case, from an inside point of view, however unscrupulous or disreputable a lender might be, it is the lender who is doing the borrower a favor. The emphasis is on the fact that the borrower needs the cash, the lender has it, and is willing to lend. The borrower will not always be able to insist easily on taking a stipulation from the lender for the return of the thing after payment. The very request for the formal promise to do one's obvious moral duty implies distrust. It might be objected that an honest lender would have no qualms about giving a stipulation; but the legal action is not needed for transactions that go well but for those that go wrong, and it is obviously aimed primarily at the dishonest creditor. ${ }^{49}$

But suppose one did not find an approach of this kind to be plausible, but insisted instead that an explanation had to be sought in economic or social needs for the emergence of the contract of pignus? That explanation would

47. See, e.g., D.13.7.9 pr; 13.6.16.1

48. Though the actio quod iussu is not evidenced for the Republic. See Watson, Obligations, supra note $27,187-88$.

49. A further reason for the introduction of the new contractual action was that it could allow more of a role for reliance on good faith even though the praetorian action did not have a condemnation clause framed ex fide bona. In favor of this explanation is the fact that fiducia - the older form of real security (and not contractual in terms of the definition given at the beginning of this paper) - was erected by using mancipatio with a special clause relating to trust and faith: see Watson, Obligations, supra note 27, $172 \mathrm{ff}$. Indeed, it is possible that the existence of fiducia was influential by way of analogy for the creation of pignus. Fiducia had two limitations: its dependence on mancipatio meant that only res mancipi could be so pledged (unless the cumbrous in iure cessio were used) and that only citizens (or those with commercium) could be creditors or debtors. The praetor might thus have introduced the very different contract of pignus, also because of the difficulties involved in framing stipulation that would adequately cover the debtor's rights. 
not be found. It is difficult to envisage much economic or social pressure for the new contractual action even when no stipulation was taken. If a repaid creditor failed or refused to return the thing pledged, the former debtor would have the ordinary action available to an owner claiming his property, which by this date would be the vindicatio. Where the creditor's behavior was theftuous, the debtor would have in addition the action on theft, the actio furti, for a penalty. Even if one assumes that from the beginning, as certainly later, the formula was also intended to give the action where the creditor returned the pledge in a damaged condition-and given the wording, the assumption seems implausible - then the debtor already had a right of action under the lex Aquilia where it was the creditor or someone in his power who did the damage negligently or maliciously. The one situation previously unprovided for but now covered by the contractual action (and within straightforward interpretation of the wording) is where the creditor failed to return the pledge because it had been stolen from him in a case in which he had been negligent. For much the same reasons, there can have been little economic need for the contract of commodatum, or as we have seen, of depositum. To a great extent we must look for an explanation in the context of the legal system.

It would not be surprising-though there is no positive evidence-to discover that the praetorian actions on deposit, loan for use, and pledge were historically linked. The action of the Twelve Tables on deposit was the result of moral outrage and, much later, the Edict limited the remedy in most cases to simple restitution. Loan for use was seen not to be dissimilar; hence likewise a contractual action was given where property in the hands of one person as a result of agreement was not duly returned to the owner; and pignus (which may or may not be older than commodatum) was seen as another example.

We have no real indications of how or when or to what end the literal contract arose, and hence no argument can be drawn from it for or against any theory of the growth of Roman contract law. It was in existence by around the beginning of the first century B.C..$^{50}$ but may well be much older. In classical law it arose when a Roman head of family marked in his account books that a debt had been paid when it had not, then made an entry to the effect that a loan had been made when it had not. ${ }^{51}$ Thus it was not an originating contract but a method of transforming one kind of obligation into another. Whether that was also the case when the literal contract first came into being, and whether in the beginning the writing had to be in the formal account books is not clear. ${ }^{52}$ The action was the actio certae pecuniae, and therefore had to be for a fixed amount of money. The literal contract was flourishing in 70 A.D. when the eruption of Vesuvius destroyed Pompeii, but it had apparently disappeared from use by the end of the classical period.

50. Cicero, de officiis, 3.58 .

51. See, e.g., Thomas, Textbook, supra note 5, $267 \mathrm{ff}$.

52. See, e.g., Watson, Obligations, supra note $27,21 \mathrm{ff}$. 
Only one standard Roman contract, societas, partnership, remains to be examined, and its origins and growth are unique. The oldest Roman partnership, ercto non cito, is very old and came into being when the head of a family died and his estate went to his sui heredes, ${ }^{53}$ that is, persons who were subject to his paternal power and on his death came to be free of any power. They were immediately partners in the inheritance and remained so until the inheritance was divided. Since persons in the power of another owned no property, the sui heredes had nothing until the inheritance came their way, hence ercto non cito is a partnership of all the property of the partners. This is not a contractual partnership, but later persons who wished to set up such a partnership were allowed to do so by means of legis actio, the archaic form of process, before the praetor. ${ }^{54}$ Eventually the praetor gave an action on a consensual contract of partnership, perhaps around the time when he created the consensual contracts of sale and hire. But this consensual contract of partnership was modelled on the old ercto non cito: significantly, the praetor set out in his Edict only one formula, a model form of action, and that was for a partnership of all of the assets of the partners. Hence, the primary type of consensual partnership was not a commercial arrangement between merchants - they would want a much more restricted partnership - but between close relatives and friends, probably wishing to engage in a communal agricultural enterprise. ${ }^{55}$ Rome had long been commercially active, and a business partnership would clearly have been economically useful, but because of legal history and legal tradition the primary instance of consensual partnership was not mercantile. Whether from the outset, as certainly was the case later, there could be partnerships of a restricted kind cannot be determined.

This origin of partnership in succession and not in business accounts for a peculiarity in consensual partnership. An heir was liable for the debts of the deceased, even if they exceeded the assets. Co-heirs would be liable for debts in the same proportion as they inherited. Hence the jurist Quintus Mucius Scaevola (killed in 82 B.C.) claimed that it was contrary to the nature of partnership that it be so set up that one partner was to take a greater share of any eventual profit than he would take of any eventual loss. ${ }^{56}$ Mucius's view is expressly based on the nature of partnership as he sees it, not on fairness. Though Servius Sulpicius successfully argued that such a partnership, and even one where one partner was entitled to share in the profit but not in any loss, was valid because that could be a fair arrangement if his services were valuable, yet Sabinus and Ulpian held that such an arrangement was valid

53. G. 3.154a.

54. G. $3.154 \mathrm{~b}$.

55. See above all Alan Watson, 'Consensual societas between Romans and the Introduction of formulae,' Revue Internationale des Droits de l'Antiquité 9 (1962) 43 lff.

56. G. 3.149. 
only if in fact it were fair. ${ }^{57}$ This is the only instance in classical Roman law 58 where a voluntary contractual arrangement entered into without error, coercion, or fraud, was valid only if there was an equivalence of contribution and reward. It owes its existence entirely to the internal logic of the legal tradition, and not at all to economic, social, or political pressures. It is the same legal logic and the piecemeal development of Roman contracts and not societal forces that either prevented the necessity for equivalence from spreading to the other bilateral contracts or from being extinguished for partnership.

The force of this internal legal logic is apparent in another failure to develop. The contracts of deposit, loan for use, and mandate grew up one by one, but once they were all in existence there was no reason for not subsuming deposit and loan for use under mandate, except that they were in fact thought of as separate institutions. It is no obstacle that deposit and commodatum required delivery of the thing for the creation of the contract. The practical effect of the law would be unchanged if these contracts were incorporated into mandate: so long as nothing had been done on a mandate either party was free to revoke or renounce unilaterally. ${ }^{59}$ There might even be doubt at times, as Pomponius discovered, whether a particular arrangement was mandate or deposit. ${ }^{60}$

The force on legal development of the lawyers' ways of looking at problems is even clearer when we look at contracts that did not develop or developed partially or late. To begin with, it is prima facie astonishing that the Romans never developed a contract in writing that would take its place by the side of stipulatio as a second contract defined by form, not by function. Such a contract would obviously have been very useful, above all for situations where the stipulatio would have been the obvious contract except that the parties could not easily be present together: these situations would include sales where warranties against eviction or latent defects were wanted. Again, a contract whose validity depended on the existence of writing would usually be easy to prove. In fact, other contracts including stipulatio ${ }^{61}$ were often reduced to writing partly in order to provide proof ${ }^{62}$ and partly to ensure that the terms were not forgotten. Nor can the Romans have been unaware of the possibility or the usefulness of written contracts:

57. D.17.2.29pr., 1: see for the argument, Alan Watson, 'The Notion of Equivalence of Contractual Obligation and Classical Roman Partnership,' Law Quarterly Review 97 (1981) $275 f f$.

58. Laesio enormis is post-classical, whether it is to be attributed to Diocletian or Justinian: C.4.44.2; 4.44.8.

59. G. 3.159; D.17.1.12.16. That damages were doubled for breach in depositum miserabile is not a problem. That could still be subjected to special regulation.

60. D.16.3.12, 13, 14.

61. D.45.1.122; 45.1.126.2; 45.1.140pr.

62. There is something illogical about accepting a written document as evidence of a stipulatio. It can show the intention of the parties, but scarcely that they went through the formalities. 
they had been standard even in classical Athens. ${ }^{63}$ And the jurist Gaius in the second century A.D. was well aware of the existence of Greek written contracts and of the contrast between them and the Roman literal contract. ${ }^{64}$ The absence of such a contract demands an explanation, which cannot be either economic or social. The most plausible explanation, I suggest, is that originally stipulation was the only contract, at a time when writing was not widespread. The habit of looking at stipulatio as the contract was so ingrained that other contracts arose as exceptions to or derogations from it only when stipulatio was obviously inappropriate. The idea of creating a new type of contract defined by form, which could be used in all situations where stipulatio could be used and in other situations where it could not, just did not occur to the Roman lawyers.

Likewise, it is equally astonishing that no contract of barter developed until the empire at the earliest. Until the introduction of coined money around 275 B.C. ${ }^{65}$ a barter-type situation must have been the most common type of commercial transaction. Even afterwards, barter would be a frequent transaction. Yet barter, permutatio, as a legal institution comes centuries later than the contract of sale, and it was never fully accepted into the Roman system of contracts. ${ }^{66}$ As a contract it was very unsatisfactory: its formation required delivery by one party, and an action for nonperformance lay only for the value of the delivered goods. Contrast this with the contract of sale that required only the agreement of the parties, and in which an action lay for a sum of money equal to what the defendant ought to give or do in accordance with good faith. Nor can one say that a contract of barter was not needed because the all-purpose stipulatio was sufficient since the contract required an oral question and answer, hence the contracting parties had to be face-to-face. For barter between merchants in different places, the only way to make an agreement for a barter situation was for one of them to send to the other, often at considerable expense and inconvenience, a dependent member of his family, such as a son or a slave to take delivery or engage in mutual stipulationes. To say that Roman merchants would not engage much in barter is to forget that the introduction of coined money into Rome is relatively late, and to say that the Roman merchants would not find the law relating to barter inconvenient is to render inexplicable the introduction of such a splendid contract as sale.

It would appear that the individual Roman contracts emerged - certainly because of societal needs - at a pace and with characteristics dictated by legal reasoning. Nothing illustrates this more clearly than a dispute between the Sabinian and the Proculian schools of jurists as to whether the price in a

63. See, e.g., Douglas M. MacDowell, The Law in Classical Athens (Ithaca, 1978) 233.

64. G. 3.134 .

65. See, e.g., Michael H. Crawford, Roman Republican Coinage (Cambridge, 1976) $35 f f$.

66. The state of development of barter before the time of Justinian is very obscure, much disputed, and need not be gone into here. For literature, see e.g., Thomas, Textbook, supra note 5, 312-13; and Kaser, Privatrecht I, supra note 4, 381. 
contract of sale could consist of a thing other than coined money. ${ }^{67}$ The Sabinians claimed that a text of Homer established that barter is the oldest form of sale. ${ }^{68}$ The Proculians, who prevailed, claimed that the Sabinians had mistranslated and argued that on that basis one could not determine what was the thing sold and what was the thing bought. At the root of the dispute is the serious business of extending satisfactory legal rules to barter. But the Sabinians, who were conscious of economic realities, were bound by the rules of the legal game and could not come out and argue for more desirable rules for barter - the most they could do was argue that barter was sale. At no point, moreover, could they argue for legal change on social or economic grounds. The Proculians, who may or may not have been blind to the economic realities, also produced arguments of a purely legal nature for their successful position. ${ }^{69}$ Law was being treated as if it were an end in itself. This indicates the existence of legal blindness. Apart from instances where it was morally impossible to demand a stipulation, the only derogations from stipulatio which were allowed to create a contract were those that involved an obligation to pay money: sale and the residual category of hire. It took even sale a very long time to break loose from the shackles of stipulatio.

David Daube, as in the case of mutuum, feels that an explanation is needed for the failure to recognize a consensual contract of barter as early as sale. And he finds that this 'phenomenon is the result of the essentially intimate nature of moneyless barter as opposed to the distant aura in money-geared sale. Even at present, as a rule, an arrangement to swap records, cameras, houses (or partners) is more private and less law-oriented than one to transfer any of these possessions for money. ${ }^{70}$ And he offers a similar explanation for the nonappearance of a contract that was akin to hire except in that neither of the prestations was in money. ${ }^{71}$ Now there is, I believe, undoubtedly much truth in the argument, but the problem of the nonappearance of these contracts is perhaps greater than Daube suggests. First, intimate contracts, not involving a money prestation, such as deposit and loan for use were recognized, provided that they were gratuitous. Second, barter between merchants would be much less intimate than the modern examples Daube suggests, especially in the days before coined money. For the absence of these transactions from the list of contracts one must add to the fact of no prestation in money the legal tradition that recognized only the stipulatio as a contract except when sufficient pressure arose in a very specific type of situation for the acceptance of a derogation from the stipulatio. Except when money was involved that pressure was

67. G. 3.141; J.3.23.1; D.19.4.1 pr.

68. For the argument see David Daube, 'Three Questions from Homer in D.18.1.1.1,' Cambridge Law Journal 10 (1949) $213 \mathrm{ff}$.

69. A relatively satisfactory outcome, I believe, from the Sabinian viewpoint would be that barter is sale, and both parties have the obligation of sellers.

70. Daube, 'Money,' supra note 18,8 .

71. Ibid. 9. 
greatest where the obligation was seen to be obviously friendly, involving trust, and hence gratuitous.

Perhaps as early as the first century A.D., the Roman jurists began to devise remedies to plug gaps in the contractual system ${ }^{72}$ - the remedy for barter seems to have been one of them. The jurist Paul in the second or third century A.D. eventually stated that an action would be given on any agreement of the following types provided the plaintiff had performed his side of the bargain: 'I give to you in order that you give, I give in order that you do, I do in order that you give, I do in order that you do. ${ }^{73}$ Thereafter any agreement containing bilateral obligations which was followed by performance by one party gave rise to an action. It is sometimes said that this is a step towards a general theory of contract. This seems incorrect. Each individual type of contract remained, each with its own major quirks. There was still no general contract law.

Finally, we should return to the oldest contract, stipulatio, which despite its long history never developed to its proper extent for reasons to be associated with the legal tradition. It is only to be expected that a very early contract is rigid, that the promisor is bound by what he says, and that the reason for his promise, even error, fraud or intimidation, is irrelevant. But once it came to be accepted, especially for the consensual contracts, that the obligations could be based on good faith, then only lawyerly conservatism and tradition would keep stipulatio a contract of strict law. There are societal advantages for the law taking good faith into account for contracts, and there is no social class of cheats. But no remedy was provided with regard to stipulatio for extortion or fraud until the first century B.C. Remedies (including action) for extortion were introduced by a praetor Octavius around 80 B.C. and for fraud by Aquillius Gallus apparently in 66 B.C. ${ }^{74}$ What concerns us are the special defenses, exceptiones, of extortion or fraud, which could be raised when an action was brought on stipulatio. The point of an exceptio is precisely that the defendant is not denying the validity of the plantiff's case. He is merely claiming that there is another fact that ought to be taken into account. In other words, extortion or fraud did not invalidate a stipulatio. It remained valid, but its effect could be negated by the use of the defense. Stipulatio always remained at this primitive level. Nor should it be thought that the distinction between invalidity and blocking by an exceptio is insignificant: if the defendant failed to plead the exceptio expressly at the appropriate time, he could not plead it later and would lose his case. No explanation for retaining a stipulation as valid but rendering it ineffective is satisfactory other than that of lawyers' ideas of what is appropriate in law.

The main thrust of this paper has been that it was Roman legal thinking, based on the tradition rooted in stipulatio as the original contract, that above all dictated the origins and nature of Roman contracts. Though

72. See the texts collected in D.19.5.

73. D. 19.5.5.pr.

74. For these see Watson, Obligations, supra note $27,257$. 
societas does not develop as a derogation from stipulatio, the mature contract, in its origins and nature, too, and also in a unique and important rule, equally demonstrates the enormous role of the legal tradition for legal evolution. None of this, of course, excludes an input into the evolution of economic forces or of the politics of power. But this input of forces outside of the legal tradition did not have a commensurate outcome. Nothing illustrates this more clearly than the relatively early actionability of contracts of depositum, commodatum, and pignus on the one hand, and the late appearance and continuing unsatisfactory state of permutatio on the other. It is not just that the first three, individually and collectively, are of much lesser commercial importance than barter; it is also that they were scarcely needed in view of existing actions in property and delict, whereas attempts to engage with legal protection in barter at a distance were fraught with inconvenience and expense. And it is surely hard to believe that the Roman merchants and others who engaged in barter had less political 'clout' than the persons who deposited their property or lent it or used it as security for a loan or who engaged in the contract of sale. 